\title{
The Current State of Knowledge on Salvia hispanica and Salviae hispanicae semen (Chia Seeds)
}

\author{
Sara Motyka ${ }^{1}$, Katarzyna Koc ${ }^{1}$, Halina Ekiert ${ }^{1}$, Eliza Blicharska ${ }^{2, *}$, Katarzyna Czarnek ${ }^{3}$ \\ and Agnieszka Szopa 1,*(D)
}

1 Chair and Department of Pharmaceutical Botany, Jagiellonian University Medical College, ul. Medyczna 9, 30-688 Kraków, Poland; sara.motyka@doctoral.uj.edu.pl (S.M.); koc.kat.17@gmail.com (K.K.); halina.ekiert@uj.edu.pl (H.E.)

2 Department of Analytical Chemistry, Medical University of Lublin, Chodźki 4a St., 20-093 Lublin, Poland

3 Institute of Health Sciences, Faculty of Science and Health Sciences in Lublin, The John Paul II Catholic University of Lublin, ul. Konstantynów 1 H, 20-708 Lublin, Poland; kczarnek@kul.pl

* Correspondence: elizablicharska@umlub.pl (E.B.); a.szopa@uj.edu.pl (A.S.); Tel.: +48-814487182 (E.B.); +48-126205430 (A.S.)

check for updates

Citation: Motyka, S.; Koc, K.; Ekiert, H.; Blicharska, E.; Czarnek, K.; Szopa, A. The Current State of Knowledge on Salvia hispanica and Salviae hispanicae semen (Chia Seeds). Molecules 2022, 27, 1207. https:// doi.org/10.3390/molecules27041207 Academic Editor: Francesco Cacciola

Received: 31 December 2021

Accepted: 2 February 2022

Published: 11 February 2022

Publisher's Note: MDPI stays neutral with regard to jurisdictional claims in published maps and institutional affiliations.

Copyright: (C) 2022 by the authors. Licensee MDPI, Basel, Switzerland. This article is an open access article distributed under the terms and conditions of the Creative Commons Attribution (CC BY) license (https:// creativecommons.org/licenses/by/ $4.0 /)$.

\begin{abstract}
Chia seeds (Salviae hispanicae semen) are obtained from Salvia hispanica L. This raw material is distinguished by its rich chemical composition and valuable nutritional properties. It is currently referred to as "health food". The purpose of the present work was to perform a literature review on S. hispanica and chia seeds, focusing on their chemical composition, biological properties, dietary importance, and medicinal uses. The valuable biological properties of chia seeds are related to their rich chemical composition, with particularly high content of polyunsaturated fatty acids, essential amino acids, polyphenols, as well as vitamins and bioelements. The available scientific literature indicates the cardioprotective, hypotensive, antidiabetic, and antiatherosclerotic effects of this raw material. In addition, studies based on in vitro assays and animal and human models have proven that chia seeds are characterized by neuroprotective, hepatoprotective, anti-inflammatory, and antioxidant properties. These properties indicate a valuable role of chia in the prevention of civilization diseases. Chia seeds are increasingly popular in functional food and cosmetic and pharmaceutical industries. That is attributed not only to their desirable chemical composition and biological activity but also to their high availability. Nevertheless, S. hispanica is also the object of specific biotechnological studies aimed at elaboration of micropropagation protocols of this plant species.
\end{abstract}

Keywords: Salvia hispanica; chia; chia seeds; essential fatty acids; essential amino acids; biological activity; medicinal uses; cosmetological application; functional food

\section{Introduction}

Salvia hispanica L. is a herbaceous plant from the genus Salvia (sage) and Lamiaceae family (Labiatae). The genus Salvia is comprised of about 900 species which occur in almost all parts of the world (North, Central, and South America, South Africa, Southeast Asia, and Europe) [1-9]. The current European Pharmacopoeia (10th edition) [10] contains monographs of raw materials obtained from different Salvia spp., namely, S. officinalis (medical sage), S. lavandulifolia (lavender sage), S. triloba (Greek sage), S. miltiorrhiza (red root sage or red sage), and $S$. sclarea (clary sage). These monographs indicate the valuable healing properties of Salvia ssp. [11]. Among the mentioned Salvia spp., S. officinalis has long been used in European medicine [12]. The other species (except S. miltiorrhiza) were introduced to official European therapy in 2008 and were included in the 6th edition of the European Pharmacopoeia. The pharmacopoeial raw materials obtained from $S$. officinalis and $S$. triloba are leaves (folium). They are a source of tannins, which have an astringent effect, and also contain essential oil (Latin: Salviae aetheroleum), which has an antiinflammatory effect $[12,13]$. Essential oils extracted from the leaves of S. lavandulifolia and 
S. sclarea also have anti-inflammatory and disinfectant properties [14,15]. A unique species of Salvia is S. miltiorrhiza, which was first introduced to official European healthcare in 2013 and included in the 7 th edition of the European Pharmacopoeia. The raw material obtained from this species is the root and rhizome (radix et rhizoma) which is rich in diterpenes (tanshinones) and salvianolic acid B. It is mainly used to treat cardiological disorders, and also has antimicrobial effects [16].

Among Salvia spp., currently one of the most valuable and widely used is undoubtedly S. hispanica L. (chia). The raw material obtained from this species is seed (Salviae hispanicae semen) (Figure 1). The species name "hispanica" incorrectly refers to the Spanish origin of the plant. This error resulted from the mistake by Carl Linnaeus who confused S. hispanica with S. lavandulifolia [17], which is known in English as "Spanish sage" and is native to Spain (and southern France) [17,18].

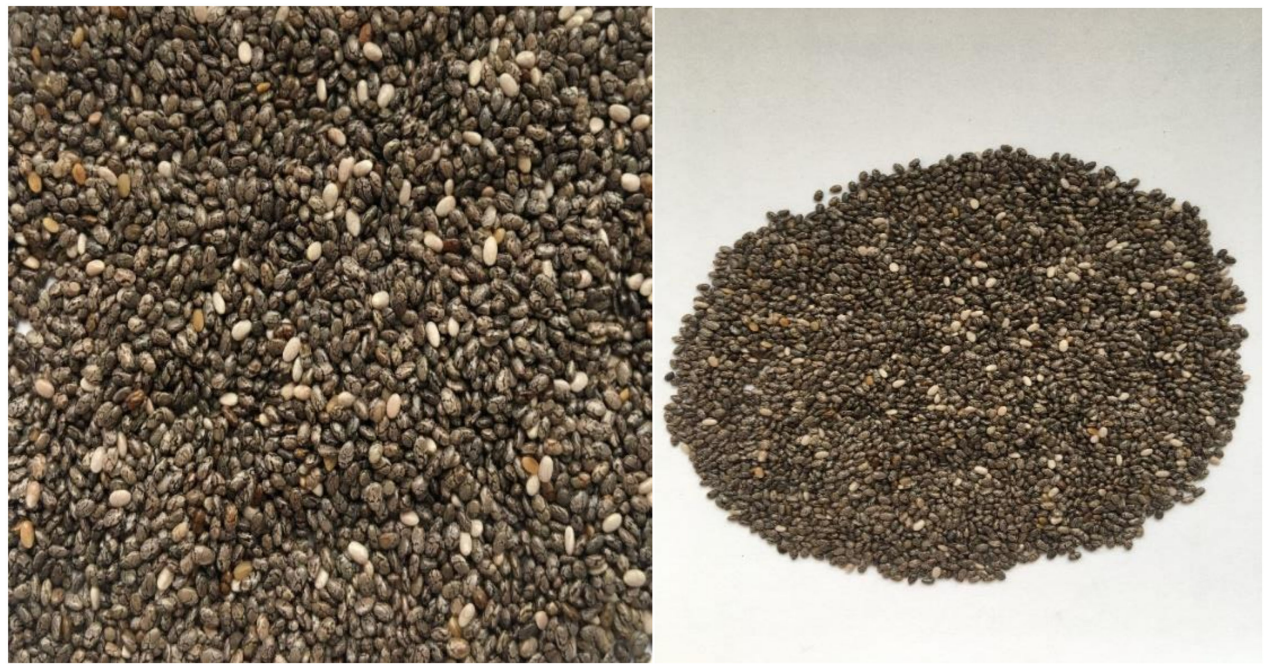

Figure 1. Morphological appearance of S. hispanica seeds.

S. hispanica, according to historic sources, was already known to the Aztecs, who used chia seeds in food and as an ingredient in many herbal mixtures, although no specific healing properties were assigned to them [3]. Oil obtained from chia seeds was also used to produce cosmetics, as a solvent for painting, and in religious rituals [19]. The term "chia" is derived from the Spanish word "chian," which means "oily" [2,4,9,20-23]. It is also thought that the word "chia" originated from the word "chihaan," from the Mayan language, meaning "strong" or "strengthening" [3]. The Plant List database provides the following Latin synonyms for S. hispanica: Kiosmina hispanica (L.) Raf., Salvia chia Colla, Salvia chia Sessé \& Moc., Salvia hispanica var. chionocalyx Fernald, Salvia hispanica var. intonsa Fernald, Salvia mexicana, Salvia neohispanica Briq., Salvia prysmatica Cav., Salvia schiedeana Stapf., and Salvia tetragona Moench [24]. The most common and colloquial name of $S$. hispanica is chia. Other names, such as "chan," "ican," and "cueruni", are used in the areas of natural habitats of the plant [3]. In Portuguese and Spanish, S. hispanica is also known as chia [25]. The species is also called chian, salvia chia, salvia chian, salba, and black chia [17].

The species S. hispanica does not have its monograph in the European Pharmacopoeia, nor in any national pharmacopoeias of the European Union and other European countries [26,27]. In 2019, the seeds of S. hispanica were approved by the European Food Safety Authority (EFSA) as a "novel food for extended uses, which allowed the inclusion of chia seeds in a variety of foods" [28,29]. Moreover, chia seeds have been added to the list of cosmetic raw materials in the CosIng database (Cosmetic Ingredient Database) which was developed by the European Commission [30].

Chia seeds, as a valuable and increasingly popular component of "healthy food", have been the focus of previously published review articles [6,9,31-39]. The authors 
emphasized the importance of chia seeds as a valuable new food resource with high health and antioxidant potential.

Their unique chemical composition and high nutritional value make chia seeds a very valuable raw material used on an industrial scale. In order to preserve all essential nutrients at high levels, the latest techniques used in nanotechnology are applicable. Nanotechnology promotes improved quality, safety, bioavailability, better controlled release, more accurate targeting, and enhances applicability. In the case of seeds obtained from oil plant species, nanoemulsions derived from seed oils are widely used to create nanocarriers that transport valuable biologically active compounds. The small particle size determines high bioavailability and gravitational stability. Encapsulation of chia seed oil results in increased bioavailability of the encapsulated active ingredient, protection from adverse effects, both natural and processed, such as chemical action, enzymatic action, and physical instability observed during processing. Encapsulation represents a very important and innovative way to improve biological performance and enhance health outcomes by controlling the delivery of active ingredients and preventing the appearance of side effects. Numerous scientific studies confirm the use of the lipid fraction of chia seeds to create nanoemulsions and nanoliposomes, which have a wide range of health-promoting therapeutic applications [39-46].

The aim of our publication is to bring together all recent scientific reports and to present, in their context, chia seeds as a raw material with a strong, well-established health-promoting position. Moreover, the paper presents information on the botanical characteristics and occurrence of S. hispanica. It describes in detail the latest scientific research on the biological activities of chia seeds in the context of their use in the treatment and prevention of civilization diseases. The paper is the latest compendium of knowledge on S. hispanica species as well as the chia seeds (Salviae hispanicae semen).

\section{Morphology, Natural Habitats, and Cultivation}

Salvia hispanica is an annual plant. It grows up to a height of $1 \mathrm{~m}$. The leaves of this plant are elongated and serrated, arranged opposite, and measure $3-5 \mathrm{~cm}$ wide and $4-8 \mathrm{~cm}$ long. The flowers are bisexual, white or purple in color, arranged in whorls, have a labial structure typical of the Lamiaceae family, and a dimension of $3-4 \mathrm{~mm}$. The seeds are oval in shape and measure 1-2 $\mathrm{mm}$ in length. They can appear uniform or as mixed and speckled (Figure 1) $[7-9,34,47,48]$. Their color can vary from white through gray to black. The white color of the seeds is a recessive trait, which is determined by a single gene and "exposed" by some chia growers. An example of the breeding variety with white seeds is S. hispanica cv. Salba. Agrisalba SA (Lima, Peru) declares that compared to darker chia seeds, white seeds have a higher and more stable content of omega- 3 fatty acids, especially $\alpha$-linolenic acid (ALA) [17,49].

Some of the features selected for cultivation and that distinguish the Salvia cultivars from wild S. hispanica are as follows: size, color, and surface area of seeds; apical dominance; increased number of branches; increased inflorescence length and calyx height; and shortened pubescence. The most important feature selected for artificial crop cultivation is closed cups, which prevent seed dispersal and eliminate domesticated varieties outside of breeding [3].

The species S. hispanica is indigenous to southern Mexico and Guatemala. It can be found in tropical and subtropical climatic zones, and its natural habitats are mostly mountainous areas. The plant grows well in sandy loam, loam, and loam soils with good drainage. It thrives mainly in acidic soils and grows best at a $\mathrm{pH}$ of 6.5-8.5. Temperatures between 11 and $36^{\circ} \mathrm{C}$ are ideal for seed growth. Under appropriate agroclimatic conditions, the plant can produce about $600 \mathrm{~kg}$ seeds/acre. Mexico is currently the world's largest producer of chia seeds. On an industrial scale, S. hispanica is cultivated almost all over the world, including Central and North America (Guatemala, Honduras, Mexico, Nicaragua, Panama, and USA), South America (Argentina, Bolivia, Brazil, Ecuador, Colombia, Paraguay, and Peru), Europe, and Australia. Seeds of S. hispanica are grown in greenhouses in Europe. 
According to data from 2014, the global artificial cultivation of S. hispanica accounted for 370,000 ha in 33 countries [34,48,50-52].

\section{Bioactive Components of S. hispanica Seeds}

Seeds are the major raw material obtained from $S$. hispanica on an industrial scale. Chia seeds are considered to have high nutritional value mainly due to their high content of polyunsaturated fatty acids (PUFA) and dietary fiber. In addition, the seeds contain wholesome protein and several phenolic compounds, macro- and microelements, and vitamins. Chia seed sprouts are also characterized by desirable chemical composition and high nutritional value [7-9,47,53].

Based on research, it has been proven that the chemical composition of chia seeds can change under the influence of various external factors. As shown by scientific studies, the content of individual nutrients can vary depending on the origin of the plant, harvesting time, storage, drying, area where the plant is grown, terrain, germination process, starting date, availability of essential nutrients, and rainfall (amount, frequency, intensity) [27,32,47,54,55].

Oil obtained from the seeds of S. hispanica accounts for 30-33\% of fatty acids [54], of which $80 \%$ are essential fatty acids (EFAs), especially PUFA (Figure S1, Supplementary Materials; Table 1). The dominant fatty acids in the oil are ALA, which is an omega-3 fatty acid constituting about $60 \%$ of the fatty acid pool, and linoleic acid (LA), which is an omega- 6 fatty acid constituting about $20 \%$ of oil. The ratio of omega- 6 to omega- 3 fatty acids in chia seeds is very favorable (around 0.3-0.35) [2,7,9,20,39,54-61]. Monounsaturated fatty acids, which belong to the group of omega- 9 fatty acids, constitute about $10 \%$ of the fatty acid pool in chia seeds, with oleic acid being dominant (Table 1). Saturated fatty acids constitute the remaining $10 \%$ of the fatty acid pool, and the dominant ones are palmitic and stearic acid (Figure S1) [62]. Compared to raw materials from other plant species, chia seeds are the richest source of ALA. Unfortunately, the high content of PUFA $(80 \%)$ in chia seeds makes them susceptible to oxidation processes, which decreases the nutritional value of the seeds [39].

Table 1. Content of the main EFAs (g/100 g dry seeds) in the S. hispanica seeds depending on their origin.

\begin{tabular}{|c|c|c|c|c|}
\hline \multicolumn{3}{|c|}{ Unsaturated Fatty Acids } & \multirow{5}{*}{ Origin of Chia Seeds } & \multirow{5}{*}{ References } \\
\hline$\alpha$-Linolenic & Linoleic & Oleic & & \\
\hline Acid (ALA) & Acid (LA) & Acid & & \\
\hline$n-3$ & n-6 & n-9 & & \\
\hline$\left(\mathrm{C}_{18} \mathrm{H}_{30} \mathrm{O}_{2}\right)$ & $\left(\mathrm{C}_{18} \mathrm{H}_{32} \mathrm{O}_{2}\right)$ & $\left(\mathrm{C}_{18} \mathrm{H}_{34} \mathrm{O}_{2}\right)$ & & \\
\hline 61.9 & 19.9 & 7.5 & West Mexico (Sinaloa) & {$[63]$} \\
\hline 63.4 & 19.8 & 8.2 & Central West Mexico (Jalisco) & [63] \\
\hline 62.02 & 17.36 & 10.55 & Southeast Brazil (Jacareia) & {$[62]$} \\
\hline 64.6 & 18.6 & 6.8 & Argentina & [64] \\
\hline 61.92 & 18.99 & 6.77 & France & [39] \\
\hline 60.94 & 19.16 & 6.87 & France & [39] \\
\hline
\end{tabular}

Carbohydrates account for $26-41 \%$ of the weight of $S$. hispanica seeds [54]. The seeds contain about $30-34 \%$ of dietary fiber (made of plant carbohydrate polymers, both oligosaccharides and polysaccharides, such as cellulose, hemicelluloses, pectic substances, and gums, which may be associated with lignin and other noncarbohydrate components) [65]. The insoluble fiber fraction of chia seeds is about $85-93 \%$, and the soluble fiber fraction is about $7-15 \%$. Chia seeds have a higher amount of dietary fiber compared to dried fruits of other plant species, cereals, and nuts, which are considered rich sources of dietary fiber $[66,67]$. 
Protein makes up $15-25 \%$ of the weight of S. hispanica seeds. The main storage protein found in chia seeds is globulin, which makes up 52\% of the total protein content. Albumins (17\%), glutelins (14\%), and prolamins (12\%) are the other proteins found in lower abundance. Chia protein has a good digestibility $(78.9 \%)$, similar to that of casein $(88.6 \%)$, higher than maize $(66.6 \%)$, rice $(59.4 \%)$, and wheat $(52.7 \%)$ proteins, but less than amaranth $(90 \%)$. In comparison to other types of cereals, such as corn seeds $(9.4 \%)$, rice $(6.5 \%)$, quinoa $(14.1 \%)$, and wheat $(12.6 \%)$, chia seeds have higher protein content. The protein fraction of chia seeds includes a set of exogenous amino acids $[9,32,34,47,60,68-70]$, namely, arginine (Arg), phenylalanine (Phe), histidine (His), isoleucine (Ileu), leucine (Leu), lysine (Lys), methionine (Met), threonine (Thr), tryptophan (Trp), and valine (Val). Endogenous amino acids found in chia seeds include: alanine (Ala), cysteine (Cys), serine (Ser), tyrosine (Tyr), aspartic acid (Asp), and glutamic acid (Glu) (Figure S2, Supplementary Materials). Among the amino acids found in S. hispanica seeds, Glu is dominant (3.50 g/100 g dry seeds). Arg and Asp are also found in a high amounts (2.14 and $1.69 \mathrm{~g} / 100 \mathrm{~g}$ dry seeds, respectively), while others constitute less than $1 \mathrm{~g} / 100 \mathrm{~g}$ dry seeds [71].

The seeds of $S$. hispanica contain polyphenol compounds that exist either in a free form or bound by glycosidic bonds with sugars. The following polyphenols have been identified in chia seeds: phenolic acids (gallic acid, caffeic acid, ferulic acid, $p$-coumaric acid), depsides (chlorogenic acid, rosmarinic acid) (Figure S3, Supplementary Materials), flavonoids (apigenin, kaempferol, quercetin, myricetin, rutoside), isoflavones (daidzein, glycitin, genistein, genistin), and catechin derivatives (including epicatechin) (Figure S4, Supplementary Materials).

Rosmarinic acid is the dominant phenolic acid with the highest concentration $(0.927 \mathrm{mg} / \mathrm{g})$, followed by protocatechuic acid $(0.747 \mathrm{mg} / \mathrm{g})$, caffeic acid $(0.027 \mathrm{mg} / \mathrm{g})$, and gallic acid $(0.012 \mathrm{mg} / \mathrm{g}$ ) (Table 2). Tannins and phytates are also found but in negligible amounts. Carotenoids (carotenes and xanthophylls) are present at an amount of about $0.5 \mu \mathrm{g} / \mathrm{g}[5,34,55]$.

Table 2. Content (mg/100 g dry seed) of phenolic acids in S. hispanica seeds-a review of studies.

\begin{tabular}{ccccccc}
\hline $\begin{array}{c}\text { Chlorogenic } \\
\text { Acid }\end{array}$ & $\begin{array}{c}\text { Ferulic } \\
\text { Acid }\end{array}$ & $\begin{array}{c}\text { Gallic } \\
\text { Acid }\end{array}$ & $\begin{array}{c}\text { Caffeic } \\
\text { Acid }\end{array}$ & $\begin{array}{c}p \text {-Coumaric } \\
\text { Acid }\end{array}$ & $\begin{array}{c}\text { Rosmarinic } \\
\text { Acid }\end{array}$ & References \\
\hline nd & $\mathrm{t}$ & 1.15 & 2.74 & nd & 92.67 & {$[72]$} \\
\hline nd & 3.587 & 4.256 & 12.536 & 2.596 & 65.398 & {$[73]$} \\
\hline $4.59-10.20$ & nd & nd & $0.30-0.68$ & nd & nd & {$[66]$} \\
\hline nd & nd & 0.005 & - & 0.024 & nd & {$[74]$} \\
\hline 0.468 & nd & nd & 3.089 & nd & nd & {$[62]$} \\
\hline nt & nt & nd & nt & nd & nt & {$[75]$} \\
\hline t-trace amounts; nd-not detected; nt-not tested. & & &
\end{tabular}

Chia seeds also contain the following sterols in small amounts: campesterol (472 mg/ $\mathrm{kg})$, stigmasterol (1248 mg/kg), $\beta$-sitosterol $(2057 \mathrm{mg} / \mathrm{kg})$, and $\Delta 5$-avenasterol $(355 \mathrm{mg} / \mathrm{kg})[34,59]$.

Furthermore, $S$. hispanica seeds contain a significant amount of valuable bioelements. These include macroelements, such as phosphorus (P), iron (Fe), manganese (Mn), calcium $(\mathrm{Ca})$, potassium $(\mathrm{K})$, magnesium $(\mathrm{Mg})$, sodium $(\mathrm{Na})$, or sulfur $(\mathrm{S})$, and microelements, such as zinc $(\mathrm{Zn})$, copper $(\mathrm{Cu})$, molybdenum (Mo), and selenium (Se) (Table 3). Compared to other cereals, such as wheat, rice, and maize, the content of $\mathrm{P}, \mathrm{Ca}, \mathrm{K}$, and $\mathrm{Mg}$ in chia seeds is higher. In addition, $S$. hispanica seeds are an especially rich source of $\mathrm{Ca}$ (560-800 mg/100 g dry seeds) and Mg (325-460 mg/100 g dry seeds) [47]. 
Table 3. Content of individual macroelements and microelements (mg/100 g dry seeds) in the $S$. hispanica seeds.

\begin{tabular}{|c|c|c|c|c|c|c|c|c|}
\hline \multicolumn{8}{|c|}{ Macroelements } & \multirow[t]{2}{*}{ References } \\
\hline $\begin{array}{l}\text { Phosphorus } \\
\text { (P) }\end{array}$ & Calcium (Ca) & $\begin{array}{l}\text { Potassium } \\
\text { (K) }\end{array}$ & $\begin{array}{l}\text { Magnesium } \\
\text { (Mg) }\end{array}$ & $\begin{array}{l}\text { Sodium } \\
\text { (Na) }\end{array}$ & Iron $(\mathrm{Fe})$ & $\begin{array}{l}\text { Manganese } \\
\text { (Mn) }\end{array}$ & $\begin{array}{l}\text { Sulfur } \\
\text { (S) }\end{array}$ & \\
\hline 860 & 631 & 407 & 335 & 16 & 7.72 & 2.72 & nt & [47] \\
\hline $530-640$ & $430-480$ & $550-620$ & $330-350$ & $140-150$ & $7.69-9.39$ & $2.48-4.05$ & $150-200$ & [76] \\
\hline $696-799$ & $580-624$ & $666-870$ & $369-403$ & nt & $10.9-24.4$ & nt & $\mathrm{nt}$ & [77] \\
\hline $901.25-1247.60$ & $561.50-806.00$ & nt & $322.00-462.40$ & nt & $11.73-14.27$ & $\mathrm{nt}$ & nt & [78] \\
\hline 919 & 456 & 726 & 449 & 0.26 & 9.18 & 3.79 & nt & [74] \\
\hline \multicolumn{9}{|c|}{ Microelements } \\
\hline \multicolumn{2}{|c|}{ Zinc (Zn) } & \multicolumn{2}{|c|}{ Copper $(\mathbf{C u})$} & \multicolumn{2}{|c|}{ Molybdenum (Mo) } & \multicolumn{2}{|c|}{ Selenium (Se) } & \\
\hline \multicolumn{2}{|c|}{4.58} & \multicolumn{2}{|c|}{0.92} & \multicolumn{2}{|c|}{0.20} & \multicolumn{2}{|c|}{0.06} & [47] \\
\hline \multicolumn{2}{|c|}{$3.65-3.76$} & \multicolumn{2}{|c|}{$0.63-1.32$} & \multicolumn{2}{|c|}{ nt } & \multicolumn{2}{|c|}{ nt } & [76] \\
\hline \multicolumn{2}{|c|}{$6.0-6.9$} & \multicolumn{2}{|c|}{ nt } & \multicolumn{2}{|c|}{$\mathrm{nt}$} & \multicolumn{2}{|c|}{0.08} & [77] \\
\hline \multicolumn{2}{|c|}{$0.60-10.00$} & \multicolumn{2}{|c|}{$1.87-2.42$} & \multicolumn{2}{|c|}{ nt } & \multicolumn{2}{|c|}{ nt } & [78] \\
\hline \multicolumn{2}{|c|}{6.47} & \multicolumn{2}{|c|}{1.86} & \multicolumn{2}{|c|}{ nt } & \multicolumn{2}{|c|}{ nt } & [74] \\
\hline
\end{tabular}

nt-not tested.

The seeds of S. hispanica contain vitamins, namely, B-complex, C, A, and E (Table 4). The content of individual vitamins in $100 \mathrm{~g}$ of dry chia seeds is: $8.83 \mathrm{mg}$ of vitamin B3, $1.6 \mathrm{mg}$ of vitamin C, $0.62 \mathrm{mg}$ of vitamin B1, $0.50 \mathrm{mg}$ of vitamin E, $0.17 \mathrm{mg}$ of vitamin B2, and $54 \mu \mathrm{g}$ of vitamin A [7,73,77]. The share of individual tocopherols in the content of vitamin is as follows: $\alpha$-tocopherol $-8 \mathrm{mg} / \mathrm{kg}, \gamma$-tocopherol $-422 \mathrm{mg} / \mathrm{kg}$, and $\delta$-tocopherol-15 mg/kg [59].

Table 4. Content of individual vitamins in the S. hispanica seeds.

\begin{tabular}{ccc}
\hline \multirow{2}{*}{ Vitamins } & \multicolumn{2}{c}{ Content (mg per 100 g of dry seeds) } \\
\cline { 2 - 3 } & $\begin{array}{c}\text { acc. to USDA (National } \\
\text { Nutrient Database for } \\
\text { Standard Reference) [71] }\end{array}$ & acc. to Knez et al. [9] \\
\hline Niacin (vitamin B3) & $8.80 \mathrm{mg}$ & $8.83 \mathrm{mg}$ \\
\hline Ascorbic acid (vitamin C) & $1.60 \mathrm{mg}$ & $1.60 \mathrm{mg}$ \\
\hline Thiamine (vitamin B1) & $0.60 \mathrm{mg}$ & $0.62 \mathrm{mg}$ \\
\hline Vitamin E & $0.50 \mathrm{mg}$ & $0.50 \mathrm{mg}$ \\
\hline Riboflavin (vitamin B2) & $0.20 \mathrm{mg}$ & $0.17 \mathrm{mg}$ \\
\hline Vitamin A & $54 \mu \mathrm{gg}$ & $54 \mu \mathrm{g}$ \\
\hline
\end{tabular}

\section{Chemical Composition of S. hispanica Leaves}

The literature indicates that the majority of studies on S. hispanica have focused on the raw material, i.e., seeds, while only a few have analyzed the chemical composition of leaves and other parts of the chia plant. Research on chia leaves looks at their antioxidant composition and antimicrobial properties [75,79].

In 2015, Amato et al. demonstrated the presence of flavonoids and derivatives of hydroxycinnamic acid in S. hispanica leaves. The flavonoid content included flavones (apigenin, luteolin, orientin, myricetin, and vitexin) as well as flavonols (derivatives of quercetin and kaempferol). In addition, researchers have isolated and identified two compounds-acetyl derivatives of vitexin and orientin. Among the derivatives of hydroxycinnamic acid, the presence of caffeic acid, $p$-coumaric acid, and rosmarinic acid was confirmed in the leaves of S. hispanica [75]. This study aimed to evaluate the an- 
tioxidant capacity of chia leaf extracts for both white and black seed phenotypes. Three methods were applied for measurements-oxygen radical absorbance capacity (ORAC), 2,2'-diphenyl-1-picrylhydrazyl (DPPH), and ORAC-Fluoresceine (ORAC-FL). In addition, cellular antioxidant activity (CAA) assays were performed on methanolic and ethanolic extracts of chia seeds. According to the ORAC-FL index values, the extracts prepared with less polar solvents (dichloromethane and hexane) had higher antioxidant capacity. Leaf extracts with black seed phenotype extracted with ethanol solvent had the highest ORAC-FL index $(2.72 \pm 0.09)$. The study documented that the ethanolic leaf extract of black phenotype showed the best quality and antioxidant capacity, both considering the stoichiometry and reactivity of antioxidants in the tested extracts. Moreover, the ethanolic extracts were found to have the highest concentration of rosmarinic acid. In extracts with more polar solvents (ethanol and ethyl acetate), the highest amounts of bioactive compounds were identified, mainly: caffeic acid, rosmarinic acid, protocatechuic acid, p-coumaric acid, coumaric acid-O-hexose, kaempferol, and genistein. In addition, the $\mathrm{F}$ isomer of salvianolic acid and dimethylquercetin were found only in ethyl acetate and dichloromethane extracts. Caffeic acid as well as rosmarinic acid have been confirmed in the S. hispanica leaf extracts before [79].

\section{Biological Activities of S. hispanica Seeds Confirmed by Scientific Research}

\subsection{Hypoglycemic, Hypotensive, Hypolipemic, Hepatoprotective, and Fat-Reducing Effects}

5.1.1. Animal Model Studies

Researchers from the University of Campinas (Campinas, São Paulo, Brazil) assessed the impact of consumed chia seeds on the metabolic rates of selected carbohydrates. They found that rats fed with a high-fat, fructose-rich diet, in which soybean oil was replaced by chia seed oil, or a high-fat, high-fructose diet containing $13.3 \%$ of chia seeds showed greater tolerance to both high glucose and high insulin levels compared to rats fed with a standard high-fat, high-fructose diet. This effect of greater glucose and insulin tolerance was observed in both short- (6-week) and long-term (12-week) dietary interventions. In addition, the group of animals consuming $S$. hispanica seeds showed a decrease in blood concentrations of non-esterified fatty acids. Furthermore, these animals showed a decrease in the level of hepatocyte damage markers, namely, alanine transaminase (ALT) and aspartate transaminase (AST), both of which tend to be increased by high-fat and highfructose diets [80].

A study conducted at the University of Litoral (Santa Fe, Argentina) demonstrated the beneficial effects of $S$. hispanica seeds on the lipid profile in rats. Rats fed with a highsucrose diet containing $2.6 \%$ of chia seeds had lower concentrations of triglycerides (TGs), non-esterified fatty acids, and total cholesterol (TC) compared to rats fed with the same diet lacking chia seeds. The addition of chia seeds to the diet had a positive effect on the glucose metabolic pathway and reduced collagen deposition in the heart of dyslipidemic, insulin-resistant rats fed with sucrose-rich diet. The levels of blood glucose were not altered in the studied rats. Additionally, a reduction in the thickness of visceral adipose tissue was observed in rats consuming chia seeds [81,82].

Subsequent studies at the same center also confirmed the beneficial effects of $S$. hispanica seeds on lipid profile. Replacing corn oil with chia seeds as a fat source in a sugar-rich diet prevented (in the group of rats in which the change was made from the beginning of the experiment) or improved and normalized (in the group of rats in which the change was made after 3 months) dyslipidemia, liver TG levels, and activities of fatty acid synthase, acetyl-CoA carboxylase, glucose-6-phosphate dehydrogenase, fatty acid oxidase, and carnitine palmitoyltransferase [64].

A team from the Federal University of Viçosa (Viçosa, Brazil) demonstrated that rats receiving a diet containing $S$. hispanica seeds or seed flour had lower blood levels of TGs, TC, low-density lipoprotein (LDL), and very-low-density lipoprotein (VLDL) compared to control rats receiving casein and non-protein diets. In addition, these animals showed 
increased levels of high-density lipoprotein (HDL) compared to controls. The study also proved that $S$. hispanica seeds exhibited hypoglycemic effects [83].

Fonte-Faria et al. from Rio de Janeiro State University (Brazil) examined the effects of diet supplemented with S. hispanica seed oil on the body weight composition and insulin signaling in the skeletal muscles of obese mice. Mice that received a chia seed oil-supplemented diet showed reduced fat accumulation and increased lean mass. In addition, these animals showed better blood glucose levels and better insulin tolerance as well as increased levels of HDL [82].

A study by Marineli et al. aimed to evaluate the effect of S. hispanica seeds and seed oil in the diet on total plasma antioxidant potential (TAS) and liver in obese rats. It was found that among rats consuming chia seeds or seed oil, there was a statistically significant increase in the activity of plasma antioxidant enzymes, i.e., catalase (CAT) and glutathione peroxidase (GPx), as well as an increase in glutathione (GSH) concentration, compared to the control group (receiving a standard diet rich in fat and fructose). In rat livers, glutathione reductase (GRd) activity was increased while CAT and GPx activities were unchanged. In addition, blood concentrations of lipid peroxidation biomarkers were decreased in animals receiving seed or seed oil diets: 8-isoprostane and TBARS (thiobarbituric acid reactive substances formed as a by-product of lipid peroxidation) compared to the control group. The assayed antioxidant capacity in plasma and liver was higher in rats receiving S. hispanica seeds and seed oil by $35 \%$ and $47 \%$, respectively, compared to the control group [67].

\subsubsection{Clinical Studies}

A study conducted at the Appalachian State University (Kannapolis, North Carolina, USA) assessed the effect of chia seed consumption on the blood levels of selected fatty acids in postmenopausal women. The results showed that daily intake of $25 \mathrm{~g}$ of chia seeds for 7 weeks resulted in an increase in the blood levels of ALA (by 138\%) and eicosapentaenoic acid (by 30\%) in the studied women. No differences were observed in the levels of docosapentaenoic and docosahexaenoic acids [74].

Researchers from the Federal University of Paraíba (João Pessoa, Brazil) investigated the effects of dietary supplementation with S. hispanica seed flour on blood pressure and the related cardiometabolic factors in treated and untreated hypertensive people. Hypertensive patients were randomly assigned to one of the following groups: group treated with the drug, untreated group, and placebo group. All patients consumed $35 \mathrm{~g}$ of chia seed flour or placebo daily for 12 weeks. The subjects who were treated with the drug and consumed S. hispanica seed flour-supplemented diet showed a decrease in mean blood pressure from 111.3 to $100.1 \mathrm{mmHg}$. The subjects who were not treated but consuming the flour-supplemented diet showed a mean decrease in systolic blood pressure from 146.8 to $137.3 \mathrm{mmHg}$. The placebo group showed no changes in blood pressure [84].

A study conducted at the Clinical Nutrition and Risk Factor Modification Centre at St. Michael's Hospital (Toronto, Canada) on patients with type 2 diabetes showed that daily intake of $15 \mathrm{~g} / 1000 \mathrm{kcal}$ of $\mathrm{S}$. hispanica seeds for 12 weeks resulted in a statistically significant reduction in the level of high-sensitivity C-reactive protein (CRP, by $40 \%$ ) as well as in the level of von Willebrand factor (by 21\%), a component of blood involved in clotting. In the patients consuming S. hispanica seeds, systolic blood pressure decreased by an average of $6.3 \mathrm{mmHg}$. No statistically significant differences in blood glucose levels or blood lipid profile parameters (TC, LDL, HDL, TGs) were observed in the studied group of patients [85]. The results of the study indicated that the hydrolysates of chia proteins, which exhibit angiotensin-converting enzyme inhibitory activity, may be responsible for the hypotensive effect of chia seeds [86,87].

The abovementioned research center also conducted a study assessing the effect of dietary supplementation with chia seeds on the reduction of postprandial glycemia. The results confirmed that this effect was dependent on the dose of chia seeds. People who consumed chia seed-enriched bread had lower postprandial glycemia compared to those 
who consumed bread without chia seed supplementation. The lowest glycemic level was found in people who consumed bread with $24 \mathrm{~g}$ of chia seeds, and the highest level in people who consumed $7 \mathrm{~g}$ of seeds. The authors of the study suggested that the fiber contained in chia seeds may be responsible for their hypoglycemic effect [88]. Another study conducted at the same research center assessed the effect of dietary supplementation with S. hispanica seeds on body weight, visceral obesity, and obesity-related risk factors in overweight or obese type 2 diabetes patients who were on a calorie-restricted diet. The first group received $30 \mathrm{~g} / 1000 \mathrm{kcal} / \mathrm{d}$ of $S$. hispanica seeds, and the second (control) group received $36 \mathrm{~g} / 1000 \mathrm{kcal} / \mathrm{d}$ of wheat bran. The primary effect observed was weight change over 6 months, and the subsequent end-effects noted were changes in waist circumference, body composition, glycemic control, and levels of CRP and obesity-related satiety hormones. After 6 months, the group receiving $S$. hispanica seeds showed a greater weight loss $(1.9 \mathrm{~kg})$ compared to the control group $(0.3 \mathrm{~kg})$, as well as a greater loss of waist circumference (by 3.5 and $1.1 \mathrm{~cm}$, respectively) [89].

The use of $S$. hispanica seeds may be effective in patients with non-alcoholic fatty liver disease (NAFLD). This is attributed to the omega-3 EFAs, dietary fiber, and polyphenols contained in chia seeds. The introduction of chia seeds in the diet may promote the reduction of intrahepatic fat in patients with NAFLD. In a study conducted by Medina-Urrutia et al. involving 25 patients with NAFLD and insulin resistance, dietary supplementation with ground chia seeds at a dose of $25 \mathrm{~g} / \mathrm{d}$ for 8 weeks resulted in a reduction in body weight (median-.4\%) and waist circumference. In addition, reductions in total cholesterol (from 4.8 to $4.6 \mathrm{mmol} / \mathrm{L}$ ) and triglyceride levels (from 1.9 to $1.6 \mathrm{mmol} / \mathrm{L}$ ) were observed in the intervention group [90].

\subsection{Antioxidant and Neuroprotective Effect}

Researchers from the State University of Maringá (Maringá, Brazil) have shown in vitro that the ingredients of $S$. hispanica seeds are capable of inactivating ABTS $\left(2,2^{\prime}\right.$-azinobis-3-ethylbenzothiazoline-6-sulfonic acid), eliminating synthetic DPPH (2,2-diphenyl-1picrylhydrazyl) radicals, and reducing iron (III) ions evaluated by FRAP (ferric reducing antioxidant power) test. The antioxidant capacity of the samples determined by ABTS, DPPH, and FRAP tests was 2.56, 1.72, and 2.86 mmol equivalent antioxidant capacity of the reference antioxidant Trolox/g sample, respectively [91].

Scientists at the National Autonomous University of Mexico (Mexico) also investigated the antioxidant activity of chia seed ingredients. They confirmed the antioxidant activity of chia seeds by the ABTS test, and through the inhibition of lipid peroxidation as well as $\beta$-carotene oxidation in the $\beta$-carotene and linoleic acid model system. The antioxidant capacity of S. hispanica seeds was found to be comparable to that of Trolox used as the reference substance. This study also confirmed the antioxidant activity of S. hispanica seed oil used in a model food emulsion of the water/oil type [66].

A study was conducted at the University of Campinas (Campinas, São Paulo, Brazil) to evaluate the effects of S. hispanica seed and seed oil added in the diet on the oxidative state of plasma and liver in obese rats. Rats consuming chia seed or oil showed significantly increased activity of antioxidant enzymes in plasma (i.e., catalase (CAT) and glutathione peroxidase (GPx)) as well as significantly increased concentration of glutathione (GSH), in comparison to the control group (receiving a standard high-fat and high-fructose diet). The activity of glutathione reductase (GRd) was found to be increased in the livers of experimental animals, while the activity of CAT and GPx remained unchanged. In addition, animals receiving seeds or seed oil in their diet showed decreased blood levels of lipid peroxidation biomarkers, namely, 8-isoprostane and TBARS (substances reacting with thiobarbituric acid, formed as a by-product of lipid peroxidation), compared to the control group. The experimental group also showed higher antioxidant capacity in plasma and liver (by 35\% and 47\%, respectively), compared to the control group [67].

A study by Leo et al. investigated the neuroprotective effects of $S$. hispanica peptide fractions. Using enzymatic hydrolysis of chia proteins, three peptide fractions $(1,1-3$, and 
3-5 $\mathrm{kDa}$ ) were produced and examined for protective and anti-inflammatory effects on HMC3 microglia cells. The 1-3 kDa fraction of chia seeds showed the greatest neuroprotective effect in HMC3 cells. Its action resulted in a reduction in the levels of inflammatory mediators (TNF- $\alpha$, IL- $6, \mathrm{NO}$, and $\mathrm{H}_{2} \mathrm{O}_{2}$ ) and reactive oxygen species (ROS). The authors suggest that the use of bioactive peptides derived from chia seeds may have beneficial applications in the prevention of neurodegenerative diseases through their anti-inflammatory and antioxidant activities [92].

\subsection{Action against Kidney Stones}

Saleem et al. in their study used a rat model of urolithiasis that was induced by the application of ethylene glycol. Added with ammonium chloride, ethylene glycol administered for three days accelerated the induction of urolithiasis in albino rats. Thirtysix rats were divided into six groups, the first group was the control, the second group had ethylene glycol $(0.75 \% \mathrm{v} / \mathrm{v})$ administered, the third group received standard drugCystone (Himalaya Drug Company, India) $(750 \mathrm{mg} / \mathrm{kg}$ b.w.), the remaining groups were administered methanolic extracts of chia seeds $(100,300$, and $700 \mathrm{mg} / \mathrm{kg}$ b.w., orally). Reduced serum creatinine, urea, uric acid, urea nitrogen, total protein, and albumin levels were observed in the experimental group after administration of the chia seed extract compared to the reference control values. In the control group where ethylene glycol was administered, creatinine, uric acid, blood urea nitrogen, total protein, and albumin levels (0.84 md/dL, $4.56 \mathrm{md} / \mathrm{dL} 14.17 \mathrm{md} / \mathrm{dL}, 6.14 \mathrm{~g} / \mathrm{dL}$, and $3.74 \mathrm{~g} / \mathrm{dL})$ were elevated compared to normal control values $(2.75 \mathrm{md} / \mathrm{dL}, 0.56 \mathrm{md} / \mathrm{dL}, 9.14 \mathrm{md} / \mathrm{dL}, 5.44 \mathrm{~g} / \mathrm{dL}$, and $3.06 \mathrm{~g} / \mathrm{dL}$ ). In addition, there was a reduction in urinary calcium, oxalate, and phosphate levels, indicating that the chia seed extract prevented urolithiasis formation. In vitro studies showed that chia seed extract prevented calcium oxalate stone formation by inhibiting the initial stages of $\mathrm{CaOx}$ crystal formation, including nucleation, aggregation, and growth phases. The authors suggested that flavonoids present in chia seeds are responsible for this activity, mainly quercetin, which through its antioxidant potential prevents the precipitation of kidney stones [36,93-95] (Table 5).

Table 5. Directions of biological activity of different $S$. hispanica seed raw materials.

\begin{tabular}{|c|c|c|c|}
\hline Profile of Action & Raw Material & Mechanism & References \\
\hline $\begin{array}{l}\text { Lipid-lowering, } \\
\text { hypoglycemic }\end{array}$ & Chia seed oil, chia seeds & $\begin{array}{l}\text { Prevention of metabolic diseases by lowering TGs, TC, } \\
\text { LDL, and VLDL and increasing HDL (by inhibiting } \\
\text { 3-hydroxy-3-methylglutaryl coenzyme A (HMG-CoA) } \\
\text { reductase), blocking the mevalonate metabolic } \\
\text { pathway, lowering ALT and ASP, improving liver } \\
\text { function, and improving postprandial glucose levels }\end{array}$ & {$[33,34,66,93]$} \\
\hline Hypotensive & $\begin{array}{l}\text { Chia seeds, chia seed flour, } \\
\text { chia seed oil }\end{array}$ & $\begin{array}{c}\text { Prevention of arterial hypertension by lowering } \\
\text { systolic blood pressure }\end{array}$ & {$[82,84,96,97]$} \\
\hline Weight-reducing & Chia seeds & $\begin{array}{l}\text { Preventing overweight and obesity by inhibiting } \\
\text { adipogenesis and reducing the level of PPAR- } \gamma \text { protein }\end{array}$ & {$[34,85]$} \\
\hline $\begin{array}{l}\text { Improving the function of } \\
\text { the digestive tract }\end{array}$ & Chia seeds & $\begin{array}{l}\text { Prevention of diseases of the gastrointestinal tract and } \\
\text { intestinal dysbiosis by improving the absorption of } \\
\text { nutrients (especially Fe and Zn), intensifying } \\
\text { fermentation processes in the intestines, and } \\
\text { increasing the production of short-chain fatty acids by } \\
\text { intestinal bacteria, surface of intestinal villi, } \\
\text { proliferation of enterocytes, and increase of beneficial } \\
\text { intestinal bacteria, mainly Bifidobacterium and } \\
\text { Lactobacillus in the cecum }\end{array}$ & [58] \\
\hline
\end{tabular}


Table 5. Cont.

\begin{tabular}{|c|c|c|c|}
\hline Profile of Action & Raw Material & Mechanism & References \\
\hline $\begin{array}{l}\text { Neuroprotective and } \\
\text { anti-inflammatory }\end{array}$ & Chia seed oil & $\begin{array}{l}\text { Prevention of neurodegenerative diseases by } \\
\text { protective effect on microglial cells (HMC3) and } \\
\text { reducing levels of inflammatory mediators (TNF- } \alpha \text {, } \\
\text { IL-6, NO, and } \mathrm{H}_{2} \mathrm{O}_{2} \text { ) and ROS. }\end{array}$ & {$[33,92]$} \\
\hline Preventing kidney stones & $\begin{array}{c}\text { Chia seed methanol } \\
\text { extract }\end{array}$ & $\begin{array}{l}\text { Prevention of kidney stones by lowering the levels of } \\
\text { creatinine, urea, and uric acid in the blood serum, } \\
\text { inhibition of the initial stages of CaOx crystal } \\
\text { formation, including nucleation, aggregation, and } \\
\text { growth phases }\end{array}$ & {$[36,93-95]$} \\
\hline Hepatoprotective & Chia seeds & $\begin{array}{c}\text { Preventing liver disease by reducing the amount of } \\
\text { intrahepatic fat, lipid deposition in hepatocytes, and } \\
\text { increasing in plasma activity of antioxidant enzymes: } \\
\text { catalase (CAT), glutathione peroxidase (GPx), and } \\
\text { glutathione (GSH) }\end{array}$ & {$[67,90]$} \\
\hline Antioxidant & Chia seeds & $\begin{array}{l}\text { Preventing inflammation by reducing the level of CRP } \\
\text { and inflammatory markers (tumor necrosis factor- } \alpha \text {, } \\
\text { nitric oxide, hydrogen peroxide, interleukin-6), } \\
\text { antiradical activity, and the ability to inhibit } \\
\text { lipoxygenase- } 5 \text { and cyclooxygenases } 1 \text { and } 2\end{array}$ & {$[47,68,69]$} \\
\hline
\end{tabular}

\subsection{Improving the Function of the Digestive Tract}

The use of soluble extracts from plants rich in dietary fiber, including chia seeds, may have a positive effect on gastrointestinal motility, improving absorption of vitamins and minerals [98-102]. Soluble extracts are obtained by isolating prebiotics from food matrices, which mostly consist of water-soluble dietary fiber. Studies show that the use of such extracts improves the absorption of nutrients by regulating the expression of specific proteins of the intestinal brush-border membrane, in addition to an increase in the surface area of the intestinal villi and increased mucilage production [103]. Administration of seed extracts causes increased fermentation processes in intestines, production of short-chain fatty acids by intestinal bacteria, which contributes to lowering of $\mathrm{pH}$ and creation of conditions unfavorable for pathogenic intestinal bacteria. When a soluble extract of plant origin is administered, there is an increase in the absorption of minerals, especially an increase in the bioavailability of zinc and iron is observed [104,105].

The study by Silva et al. was designed to evaluate the effect of intra-amniotic administration of soluble methanolic prebiotic chia extracts on Fe and Zn levels and on brush-border membrane functionality in vivo. Researchers demonstrated that the use of methanolic extract of chia seeds results in a beneficial improvement in intestinal function; including increased surface area, thickness, and width of intestinal villi, increased proliferation of enterocytes, and increased mucilage secretion through an increase in the number of goblet cells. The researchers also examined the effects of the extracts on changes in intestinal bacterial populations and intestinal morphology.

The levels of $\mathrm{Fe}, \mathrm{Zn}$, insoluble fiber fraction, and phytic acid content were higher in chia seeds compared to chia seed extract. However, the water-soluble fiber content was significantly higher in chia seed extract compared to chia seeds. In the groups treated with chia extract, the area, length, and width of intestinal villi, including cecal mass, were higher compared to the control group. The researchers concluded that soluble chia extracts had beneficial effects on intestinal microflora by affecting enterocyte proliferation and increasing the number of mucus-producing cells, this may increase the digestive and absorption capacity of the intestinal brush-border membrane (BBM). In addition, the use of chia extract resulted in an increase in cup cell diameter compared to the control group. Administration of soluble chia seed extracts enhanced the expression of proteins involved in zinc metabolism. In the group treated with chia extract (2.5\%), the expression of DMT1 
(divalent metal transporter 1) genes was lower compared to the control group. Moreover, other concentrations of methanolic chia extract did not affect DMT1 gene expression. DcytB (duodenal cytochrome b) and hepcidin expression were significantly increased in the groups treated with $1 \%, 2.5 \%$, and $5 \%$ chia extract, which could potentially increase the efficiency of iron absorption. In addition, groups treated with $1 \%, 2.5 \%$, and $5 \%$ chia extract had lower ferroportin gene expression compared to other groups. There was also a beneficial effect of the administration of soluble chia extracts $(0.5 \%)$ on the composition of the intestinal microflora by increasing the number of beneficial intestinal bacteria of the genera Bifidobacterium and Lactobacillus in the cecum. Increased numbers of Lactobacillus and Bifidobacterium may also contribute to increased bioavailability of minerals, as these bacteria produce short-chain fatty acids (SCFAs) that lower intestinal $\mathrm{pH}$ and therefore may increase solubility and absorption of Fe and Zn. In this study, intra-water (in ovo) administration of soluble chia seed extracts was shown to benefit gastrointestinal function by increasing mineral bioavailability and improving intestinal morphology [56] (Table 5).

\section{Application of S. hispanica in Cosmetology}

CosIng (Cosmetic Ingredient Database), a database developed by the European Commission, contains information on cosmetic substances authorized by the European legislation for the production of cosmetics.

The CosIng database provides information on six raw materials obtained from $S$. hispanica: whole and powdered seeds, chia seed extract and oil, and S. hispanica herb extract and oil. It also has data on the activity profile of raw materials, including the peeling and softening of seeds, as well as moisturizing and nourishing effects of seed oil. In addition, $S$. hispanica oil and herb extract are used for flavoring and recommended for the production of perfumes (Table 6) [30].

Table 6. Raw materials obtained from S. hispanica registered in the CosIng database along with their uses [30].

\begin{tabular}{|c|c|}
\hline Name according to CosIng & Application \\
\hline S. hispanica seed & Abrasive, scrubbing agent \\
\hline S. hispanica seed powder & Abrasive, scrubbing agent \\
\hline S. hispanica seed oil & Moisturizing agent, nourishing effect on the epidermis \\
\hline S. hispanica seed extract & Emollient, nourishing effect on the epidermis \\
\hline S. hispanica herb oil & $\begin{array}{c}\text { For the production of perfumes and aromas, functional } \\
\text { fragrances }\end{array}$ \\
\hline S. hispanica herb extract & $\begin{array}{c}\text { For the production of perfumes and aromas, functional } \\
\text { fragrances }\end{array}$ \\
\hline
\end{tabular}

The health-promoting effects of phenolic acids present in chia seeds, which have antioxidant and antimicrobial properties, are particularly exploited in cosmetology. Due to these properties, phenolic acids are used in cosmetology and dermatology. These compounds can be found in both generally available cosmetic preparations, as well as in professional preparations used for treatments in beauty salons. Treatments with these acids counteract photoaging of the skin and also show depigmentation properties by controlling the activity of tyrosinase, which maintains an even pigmentation of the skin. In addition, phenolic acids alleviate the symptoms of acne and atopic dermatitis [106]. Table 6 shows the main raw materials extracted from $S$. hispanica registered in the CosIng database along with their uses.

The raw materials obtained from $S$. hispanica are especially applied in the production of natural and vegan cosmetics that are currently widely available on the market. The most common ingredients used in these cosmetics are chia seed oil and extract. Chia seed oil is also sold alone as a cosmetic product. The cosmetics prepared using S. hispanica extract 
and seed oil include hand and face creams, face oils, masks, foundations, micellar lotions, body lotions, shower gels, soaps, deodorants, shampoos, and hair conditioners. In all these cosmetics, chia extract and seed oil serve as a nourishing and moisturizing agent $[107,108]$. In addition, oil-in-water emulsions containing chia seeds are widely used in cosmetology, where they show a moisturizing effect on the skin (Table 6). Researchers at Korea University, College of Medicine (Ansan, South Korea), evaluated the benefits of topical application of omega-3-rich foods to the skin. They tested an oil/water emulsion containing $4 \% S$. hispanica seed oil on five healthy volunteers with symptoms of xerotic pruritus and five patients with pruritus caused by end-stage renal disease or diabetes. After eight weeks of use, all patients showed a significant improvement in skin hydration, as well as an improvement in the epidermal barrier function, as confirmed by reduced transepidermal water loss and increased skin hydration. Application of the topical preparation with chia seed oil also reduced itching in all patients, with no adverse effects [109].

\section{Applications of Chia Seeds in the Food Industry}

Chia seeds are widely used in food production, especially in the functional food, due to their high lipid content (30-33\%), proteins (15-25\%), carbohydrates (26-41\%), vitamins, bioelements, and dietary fiber (18-30\%) [33,47,54,55]. The caloric value of $100 \mathrm{~g}$ of dry seeds is $486 \mathrm{kcal}$ [71]. In 2019, the EFSA confirmed that chia seeds are safe to use in food products $[28,29]$. It was also shown that chia seeds do not contain mycotoxins or harmful levels of heavy metals [28,110]. According to the Advisory Committee on Novel Foods and Processes in the UK, adults should consume on average $2.1 \mathrm{~g}$ of chia seeds per day, with a maximum of $12.9 \mathrm{~g}$ (approximately a spoonful). The average level of consumption for children aged 1.5-4.5 years should be $1.1 \mathrm{~g}$ /day (maximum $3.2 \mathrm{~g} /$ day), and for those aged 4.5-19 years, the daily intake should not exceed $4.3 \mathrm{~g} /$ day [58].

Chia seeds are used in the food industry in the form of whole seeds, ground seeds, seed flour, or seed oil [7,111]. They can be added to various food products, such as juices, yogurts, cakes, cookies, bread, pasta, ice cream, desserts, breakfast cereals, and even sausages and hams. Chia seed oil is also available on the market and is recommended as an additive for sandwiches, salads, cottage cheese, and spreads. The US dietary guidelines published in 2000 recommend that chia seeds can be consumed at an amount not exceeding $48 \mathrm{~g} /$ day [8]. In addition, a new regulation was implemented in 2017 stating the maximum amount of chia seeds that can be included in bread products (5\% whole seeds), breakfast cereals (10\% whole seeds), baked goods (10\% whole seeds), fruit and seed mixtures $(10 \%$ whole seeds), fruit spreads (1\% whole seeds), yogurts (1.3 g whole seeds / $100 \mathrm{~g}$ yogurt or $4.3 \mathrm{~g} / 330 \mathrm{~g}$ yogurt), fruit and vegetable juices and drinks (15 g/d whole or ground seeds), and ready-to-eat products (5\% whole seeds) [29].

Due to their hydrophilic properties, chia seeds are used as an alternative to eggs and fat [112-115]. The seeds provide a characteristic mucilage texture to food and can absorb water up to 12 times their own weight [64]. Chia seed mucilage can stabilize emulsions; however, this property is influenced by the composition of the emulsion, and compared to other hydrocolloids, such as acacia gum, modified starch, and cellulose, chia seed mucilage has a low emulsifying activity index. Moreover, mucilage obtained from chia seeds is a rich source of polysaccharides, mainly cellulose, and hence can be used in the production of edible films and coatings [2,23].

Due to the fact, that chia seeds are a good source of omega- 3 fatty acids (and have a favorable ratio of omega-3 to omega- 6 fatty acids), they are commonly used by people on plant-based diets such as vegetarians or vegans [116]. In addition, due to the absence of gluten, chia seeds are a valuable ingredient for people with celiac disease to increase the nutritional value of the diet and for people on a gluten-free diet. Furthermore, wheat flour is substituted by chia seed skim flour as it contains more protein, dietary fiber, and bioactive compounds. In a study by Martinez et al., the nutritional and sensory properties of wheat flour biscuits were compared with biscuits containing skimmed chia, sesame, linseed, and poppy seeds. The authors found that biscuits baked using flour from various 
types of skimmed seeds contained twice as much protein as those made of wheat flour. Moreover, the content of dietary fiber and protein was the highest in cookies prepared using chia seed flour $[48,63]$.

Chia seeds have also been used in meat processing, as an additive to sausages, for improving their nutritional and technological value. A study assessed the effect of $S$. hispanica seeds on lipid oxidation and proved that the addition of $0.5-1 \%$ chia seeds resulted in a reduction of fat oxidation in the meat product. This was attributed to the presence of numerous polyphenolic compounds, characterized by antioxidant activity, in chia seeds [33,117].

\section{Plant Biotechnology Studies of S. hispanica}

A review of the scientific literature shows that there are very few scientific papers on in vitro cultures studies of $S$. hispanica. These studies mainly concern the elaboration of micropropagation protocols-a technique used for rapid multiplication in vitro. Their short descriptions to date are briefly described below.

The aim of the study conducted by Carvalho et al. was to produce micropropagated $S$. hispanica embryos on two types of liquid medium. The researchers created MurashigeSkoog (MS) liquid medium, which differed in the presence of sucrose. After disinfecting the seeds, they were placed in glass vials with MS liquid medium with sucrose ( $30 \mathrm{~g} / \mathrm{L})$, (and without sucrose) and with plant growth regulators (PGRs). Cultures were grown at 25 $\pm 2{ }^{\circ} \mathrm{C}$ in a photoperiod of $16 / 8 \mathrm{~h}$. Higher germination was observed in cultures grown on sucrose-containing media compared to media without sucrose. It was found that seedlings at day 14 had the highest shoot and root growth [118].

Zayova et al. conducted also a study on micropropagation of S. hispanica. High percentage of seed germination $(100 \%)$ was recorded on MS medium enriched with $0.4 \mathrm{mg} / \mathrm{L}$ gibberellic acid $\left(\mathrm{GA}_{3}\right)$ and $10 \mathrm{mg} / \mathrm{L}$ ascorbic acid after one week of culture. The maximum number of shoots per explant was obtained in cultures conducted on MS medium with $2 \mathrm{mg} / \mathrm{L}$ 6-benzyladenine (BA) after five weeks of culture. The best rooting of plants was achieved on MS medium with $0.1 \mathrm{mg} / \mathrm{L}$ indolyl-3-butyric acid (IBA) after four weeks of culture. Many plants were successfully adapted to ex vitro conditions with $95 \%$ survival rate [119].

Yadav et al. developed another micropropagation protocol for S. hispanica. S. hispanica seeds were germinated aseptically on $\frac{1}{2}$ MS medium. Nodal explants obtained from in vitro germinated seedlings were maintained on MS medium with BA $(1-5 \mathrm{mg} / \mathrm{L})$ or kinetin (KIN) (1-5 mg/L) individually or with the addition of 1-naphthaleneacetic acid (NAA) $(0.1-1 \mathrm{mg} / \mathrm{L})$ and indolyl-3-acetic acid (IAA) $(0.1-1 \mathrm{mg} / \mathrm{L})$. The highest number of shoots per explant $(9.02 \pm 2.65)$ was found on culture medium containing $3 \mathrm{mg} / \mathrm{L} \mathrm{BA}$, which was also optimal for growth of regenerated shoots. Rooting was obtained on $\frac{1}{2}$ MS medium with $1 \mathrm{mg} / \mathrm{L} \mathrm{IBA}$. The rooted shoots were acclimatized and transferred to natural conditions with $75 \%$ survival rate [120].

Marconi et al. initiated and optimized culture conditions for shoot and callus cultures of $S$. hispanica. Stem fragments were the best explant source to initiate in vitro cultures. Both used PGRs, IAA $(0.57,2.85,5.70 \mu \mathrm{mol} / \mathrm{L})$ and NAA $(0.54,2.70,5.40 \mu \mathrm{mol} / \mathrm{L})$, with or without BA $(0.50 \mu \mathrm{mol} / \mathrm{L})$ or KIN $(0.46 \mu \mathrm{mol} / \mathrm{L})$, induced adventitious root formation, both in the dark and in the light. In the dark, 2,4-dichlorophenoxyacetic acid (2,4-D) stimulated the development of $S$. hispanica embryogenic tissues, while in the light it promoted the initiation and formation of green and fast-growing callus, which lost their fragility over time. However, callus cultured on MS medium with NAA as PGR, maintained vitality for two years. Fatty acids were determined in the obtained callus cultures, but their content $(0.73 \mathrm{~g} / 100 \mathrm{~g}$ fresh weight) was much lower than in the seeds of parent plants (30.22 g/100 g fresh weight) [121].

Bueno et al. evaluated the in vitro behavior of different $S$. hispanica explants as material for the initiation of in vitro cultures. The explants tested were: young leaves, cotyledons, and stem fragments with two lateral buds. Explants were inoculated on MS culture 
medium with $0.1 \mu \mathrm{M}$ of NAA; $0.1 \mu \mathrm{M}$ of $\mathrm{GA}_{3}$; and $0,0.5,0.75$, or $1 \mu \mathrm{M}$ of BA. Inoculation of both leaves and cotyledons was unsuccessful. The good results of in vitro shoot survival were obtained for stem fragments. Furthermore, the greater plant proliferation, with up to 6.63 shoots per bud, was observed for BA in concentrations 0.75 and $1 \mu \mathrm{M}$. Higher concentrations of BA increased in vitro shoot formation [122].

\section{Conclusions}

Salvia hispanica L. is a plant species that has been used since antiquity and is now highly valued for its unique nutritional and potential medicinal properties. Chia seeds have recently become one of the most popular food ingredients, with a number of beneficial effects on the functioning of the human body. The data presented under our review indicate that they are also a valuable health-promoting dietary supplement as well as cosmetic ingredient. Scientific studies on pharmacological activities of chia seeds proved their potential valuable role in the prevention of diseases which currently are considered a global health problem. The research confirmed the cardioprotective, antihypertensive, antidiabetic, antiatherosclerotic, nephroprotective, anti-inflammatory, as well as antioxidant properties.

In recent years, chia seeds have been gaining popularity in food, diet supplement, and cosmetic industries, not only due to their valuable chemical composition and biological activity, but also due to their availability. Although $S$. hispanica occurs in very few natural habitats (Central America), it is successfully cultivated in many parts of the world. The popularity of $S$. hispanica is evidenced by (so far few) research in the field of plant biotechnology, the aim of which is to develop effective protocols for micro-propagation of this species under in vitro conditions.

Currently, chia seeds and products containing S. hispanica seed or herb extract or oil are widely available in health food stores, pharmacies, cosmetic stores, hypermarkets, and online stores.

The properties of S. hispanica species thanks to the seeds, undoubtedly merit special attention and interest. Due to their wide range of action and therapeutic value, chia seeds may be more widely used in the future, and Salviae hispanicae semen can be possibly included in the pharmacopoeial monographs of the European Union and other countries.

Supplementary Materials: The following are available online Figure S1. Chemical structures of the main fatty acids present in S. hispanica seeds; Figure S2. Chemical structures of the main amino acids present in S. hispanica seeds; Figure S3. Chemical structure of the main phenolic acids present in $S$. hispanica seeds; Figure S4. Chemical structures of the main flavonoids and epicatechin present in $S$. hispanica seeds.

Author Contributions: Data collection, S.M., K.K. and A.S.; design of the study: A.S.; analysis and interpretation of the data, S.M., K.K. and A.S.; drafting the manuscript, S.M., H.E., E.B., K.C. and A.S.; critical revision of the manuscript, S.M., H.E. and A.S. All authors have read and agreed to the published version of the manuscript.

Funding: This study received no external funding.

Conflicts of Interest: The authors declare no conflict of interest.

\section{References}

1. Lu, Y.; Foo, L.Y. Polyphenolics in Salvia. Phytochemistry 2002, 59, 117-140. [CrossRef]

2. Segura-Campos, M.R.; Ciau-Solís, N.; Rosado-Rubio, G.; Chel-Guerrero, L.; Betancur-Ancona, D. Chemical and Functional properties of chia seed (Salvia hispanica L.) gum. Int. J. Food Sci. 2014, 1-5. [CrossRef] [PubMed]

3. Cahill, J.P. Ethnobotany of chia, Salvia hispanica L. (Lamiaceae). Econ. Bot. 2003, 57, 604-618. [CrossRef]

4. Ayerza, R.; Coates, W. Chia: Rediscovering a Forgotten Crop of the Aztecs; University of Arizona Press: Tucson, AZ, USA, 2005.

5. Uribe, J.A.R.; Perez, J.I.N.; Kauil, H.C.; Rubio, G.R.; Alcocer, C.G. Extraction of oil from chia seeds with supercritical $\mathrm{CO}_{2}$. J. Supercrit. Fluids. 2011, 56, 174-178. [CrossRef]

6. $\quad$ Enes, B.N.; Moreira, L.P.D.; Silva, B.P.; Grancieri, M.; Lúcio, H.G.; Venâncio, V.P.; Mertens-Talcott, S.U.; Rosa, C.O.B.; Martino, H.S.D. Chia seed (Salvia hispanica L.) effects and their molecular mechanisms on unbalanced diet experimental studies: A systematic review. J. Food Sci. 2020, 85, 226-239. [CrossRef] 
7. $\quad$ Das, A. Advances in chia seed research. Adv. Biotechnol. Microbiol. 2017. [CrossRef]

8. Norlaily, M.; Yeap, A.K.S.; Wan, Y.H.; Boon, K.B.; Sheau, W.T.; Soon, G.T. The promising future of chia, Salvia hispanica L. J. Biomed. Biotechnol. 2012. [CrossRef]

9. Hrnčič, K.; IvanovskI, C. Chia seeds (Salvia hispanica L.): An overview-Phytochemical profile, isolation methods, and application. Molecules 2019, 25, 11. [CrossRef]

10. European Directorate for the Quality of Medicines. European Pharmacopoeia 9.0; European Directorate for the Quality of Medicines: Strasbourg, France, 2017.

11. Perry, E.K.; Pickering, A.T.; Wang, W.W.; Houghton, P.J.; Perry, N.S.L. Medicinal plants and Alzheimer's disease: From ethnobotany to phytotherapy. J. Pharm. Pharmacol. 2010, 51, 527-534. [CrossRef]

12. Ghorbani, A.; Esmaeilizadeh, M. Pharmacological properties of Salvia officinalis and its components. J. Tradit. Complement. Med. 2017, 7, 433-440. [CrossRef]

13. Lopresti, A.L. Salvia (sage): A review of its potential cognitive-enhancing and protective effects. Drugs $R D$ 2017, 17, 53-64. [CrossRef] [PubMed]

14. Porres-Martinez, M.; Accame, M.; Gómez-Serranillos, M. Pharmacological activity of Salvia lavandulifolia and chemical components of its essential oil. A Review. Lazaroa 2013, 34, 237-254. [CrossRef]

15. Yang, H.J.; Kim, K.Y.; Kang, P.; Lee, H.S.; Seo, G.H. Effects of Salvia sclarea on chronic immobilization stress induced endothelial dysfunction in rats. BMC Complement. Altern. Med. 2014, 14, 396. [CrossRef] [PubMed]

16. Su, C.Y.; Ming, Q.L.; Rahman, K.; Han, T.; Qin, L.P. Salvia miltiorrhiza: Traditional medicinal uses, chemistry, and pharmacology. Chin. J. Nat. Med. 2015, 13, 163-182. [CrossRef]

17. Baldivia, A.S. A historical review of the scientific and common nomenclature associated with chia: From Salvia hispanica to Salvia mexicana and chian to salba. Agric. Res. Technol. Open Access J. 2018, 18, 1-8. [CrossRef]

18. Cafligueral, S.; Iglesias, J.; Hamburger, M.; Hostettmann, K. Phenolic constituents of Salvia lavandulifolia ssp. lavandulifolia. Phytochemistry 1989.

19. Craig, R.; Sons, M. Application for Approval of Whole Chia (Salvia hispanica L.) Seed and Ground Whole Seed as Novel Food Ingredient. 2004. Available online: https://acnfp.food.gov.uk/sites/default/files/mnt/drupal_data/sources/files/multimedia/ pdfs/chiaapplication.pdf (accessed on 3 December 2021).

20. Ayerza, R.; Coates, W. Protein content, oil content and fatty acid profiles as potential criteria to determine the origin of commercially grown chia (Salvia hispanica L.). Ind. Crops Prod. 2011, 34, 1366-1371. [CrossRef]

21. Coates, W. Whole and ground chia (Salvia hispanica L.) seeds, chia oil-Effects on plasma lipids and fatty acids. In Nuts and Seeds in Health and Disease Prevention; Academic Press: London, UK, 2011; pp. 309-315.

22. Suri, S.; Passi, S.J.; Goyat, J. Chia seed (Salvia hispanica L.)—A new age functional food. Int. J. Adv. Technol. Eng. Sci. 2016, 4, 286-299.

23. Muñoz, L.; Cobos, A.; Diaz, O.; Aguilera, J. Chia seeds: Microstructure, mucilage extraction and hydration. J. Food Eng. 2012, 108, 216-224. [CrossRef]

24. The Plant List-A Working List of All Plant Species. Available online: http:/ / www.theplantlist.org/ (accessed on 12 September 2020).

25. World Flora Online. Available online: http://www.worldfloraonline.org/taxon/wfo-0000301201\#localNames (accessed on 12 September 2020).

26. European Directorate for the Quality of Medicines. European Pharmacopoeia 10.0; European Directorate for the Quality of Medicines: Strasbourg, France, 2020.

27. Nieman, C.; Cayea, E.J.; Austin, M.D.; Henson, D.A.; McAnulty, F.J. Chia seed does not promote weight loss or alter disease risk factors in overweight adults. Nutr. Res. 2009, 29, 414-418. [CrossRef]

28. Turck, D.; Castenmiller, J.; de Henauw, S.; Hirsch-Ernst, K.I.; Kearney, J.; Maciuk, A.; Mangelsdorf, I.; McArdle, H.J.; Naska, A.; Pelaez, C.; et al. Safety of chia seeds (Salvia hispanica L.) as a novel food for extended uses pursuant to Regulation (EU) $2015 / 2283$. EFSA J. 2019, 17, e05657. [CrossRef]

29. Turck, D.; Castenmiller, J.; de Henauw, S.; Hirsch-Ernst, K.I.; Kearney, J.; Maciuk, A.; Mangelsdorf, I.; McArdle, H.J.; Naska, A.; Pelaez, C.; et al. Safety of chia seeds (Salvia hispanica L.) powders, as novel foods, pursuant to Regulation (EU) 2015/2283. EFSA J. 2019, 17, e05716. [CrossRef] [PubMed]

30. European Commission CosIng-Cosmetic Database. Available online: https://ec.europa.eu/growth/sectors/cosmetics/cosmeticingredient-database_en (accessed on 10 October 2021).

31. Kang, Y.; Ha, W.; Liu, Y.-Q.; Ma, Y.; Fan, M.-M.; Ding, L.-S.; Zhang, S.; Li, B.-J. PH-responsive polymer-drug conjugates as multifunctional micelles for cancer-drug delivery. Nanotechnology 2014, 25, 335101. [CrossRef] [PubMed]

32. Kulczyński, B.; Kobus-Cisowska, J.; Taczanowski, M.; Kmiecik, D.; Gramza-Michałowska, A. The chemical composition and nutritional value of chia seeds—current state of knowledge. Nutrients 2019, 11, 1242. [CrossRef] [PubMed]

33. Rabail, R.; Khan, M.R.; Mehwish, H.F.; Rajoka, M.S.R.; Lorenzo, J.M.; Kieliszek, M.; Khalid, A.R.; Shabbir, M.A. An overview of chia seed (Salvia hispanica L.) bioactive peptides' derivation and utilization as an emerging nutraceutical food. Front. Biosci. 2021, 26, 643. [CrossRef]

34. Grancieri, M.; Martino, H.S.D.; Gonzalez de Mejia, E. Protein digests and pure peptides from chia seed prevented adipogenesis and inflammation by inhibiting PPAR $\gamma$ and NF-kB pathways in 3T3L-1 adipocytes. Nutrients 2021, 13, 176. [CrossRef] 
35. Miranda-Ramos, K.C.; Haros, C.M. Combined effect of chia, quinoa and amaranth incorporation on the physico-chemical, nutritional and functional quality of fresh bread. Foods 2020, 9, 1859. [CrossRef]

36. Saleemnazir, U.; Ahmad, M.; Ajmal Shah, M.; Fareeha, A.; Ahmad, B. Anti-urolithiatic activity of Salvia hispanica L. seeds in ethylene glycol induced urolithiasis rat's model. Health Sci. 2020, 92, e20200067. [CrossRef]

37. Miranda-Ramos, K.; Millán-Linares, M.C.; Haros, C.M. Effect of chia as breadmaking ingredient on nutritional quality, mineral availability, and glycemic index of bread. Foods 2020, 9, 663. [CrossRef] [PubMed]

38. Motyka, S.; Ekiert, H.; Szopa, A. Chemical composition, biological activity and utilization of chia seeds (Salviae hispanicae semen) Farm. Pol. 2021, 77, 651-661. [CrossRef]

39. Kuznetcova, D.V.; Linder, M.; Jeandel, C.; Paris, C.; Desor, F.; Baranenko, D.A.; Nadtochii, L.A.; Arab-Tehrany, E.; Yen, F.T. Nanoliposomes and nanoemulsions based on chia seed lipids: Preparation and characterization. Int. J. Mol. Sci. 2020, $21,9079$. [CrossRef]

40. McClements, D.J. Nanoemulsion-based oral delivery systems for lipophilic bioactive components: Nutraceuticals and pharmaceuticals. Ther. Deliv. 2013, 4, 841-857. [CrossRef] [PubMed]

41. Danaei, M.; Dehghankhold, M.; Ataei, S.; Hasanzadeh Davarani, F.; Javanmard, R.; Dokhani, A.; Khorasani, S.; Mozafari, M. Impact of particle size and polydispersity index on the clinical applications of lipidic nanocarrier systems. Pharmaceutics 2018, 10, 57. [CrossRef]

42. Teng, J.; Hu, X.; Wang, M.; Tao, N. Fabrication of chia (Salvia hispanica L.) seed oil nanoemulsions using different emulsifiers. J. Food Process. Preserv. 2018, 42, e13416. [CrossRef]

43. Ferreira, C.D.; Nunes, I.L. Oil nanoencapsulation: Development, application, and incorporation into the food market. Nanoscale Res. Lett. 2019, 14, 9. [CrossRef] [PubMed]

44. Chau, C.-F.; Wu, S.-H.; Yen, G.-C. The development of regulations for food nanotechnology. Trends Food Sci. Technol. 2007, 18, 269-280. [CrossRef]

45. De Vos, P.; Faas, M.M.; Spasojevic, M.; Sikkema, J. Encapsulation for preservation of functionality and targeted delivery of bioactive food components. Int. Dairy J. 2010, 20, 292-302. [CrossRef]

46. Rodríguez, J.; Martín, M.J.; Ruiz, M.A.; Clares, B. Current encapsulation strategies for bioactive oils: From alimentary to pharmaceutical perspectives. Food Res. Int. 2016, 83, 41-59. [CrossRef]

47. Ullah, R.; Nadeem, M.; Khalique, A.; Imran, M.; Mehmood, S.; Javid, A.; Hussain, J. Nutritional and therapeutic perspectives of Chia (Salvia hispanica L.): A review. J. Food Sci. Technol. 2016, 53, 1750-1758. [CrossRef]

48. Muñoz, L.A.; Cobos, A.; Diaz, O.; Aguilera, J.M. Chia seed (Salvia hispanica): An ancient grain and a new functional food. Food Rev. Int. 2013, 29, 394-408. [CrossRef]

49. Ulbricht, C.; Chao, W.; Nummy, K.; Rusie, E.; Tanguay-Colucci, S.; Iannuzzi, C.; Plammoottil, J.; Varghese, M.; Weissner, W. Chia (Salvia hispanica): A systematic review by the natural standard research collaboration. Rev. Recent Clin. Trials. 2009, 4, 168-174. [CrossRef]

50. Bordin-Rodrigues, C.J. Management, bean and chia development in accordance with fertilization. Heliyon 2021, 7, e07316. [CrossRef]

51. Benetoli da Silva, T.R.; de Melo, S.C.; Nascimento, A.B.; Ambrosano, L.; Bordin, J.C.; Alves, C.Z.; Secco, D.; Santos, R.F.; Gonçalves, A.C., Jr.; da Silva, G.D. Response of chia (Salvia hispanica) to sowing times and phosphorus rates over two crop cycles. Heliyon 2020, 6, e05051. [CrossRef] [PubMed]

52. Huxley, A.J. The New RHS Dictionary of Gardening; Mac Millan Press: London, UK, 1992.

53. Kris-Etherton, P.M.; Hecker, K.D.; Bonanome, A.; Coval, S.M.; Binkoski, A.E.; Hilpert, K.F.; Griel, A.E.; Etherton, T.D. Bioactive compounds in foods: Their role in the prevention of cardiovascular disease and cancer. Am. J. Med. 2002, 113, 71-88. [CrossRef]

54. Da Luz, J.M.R.; Nunes, M.D.; Paes, S.A.; Torres, D.P.; Silva, M.D. Lignocellulolytic enzyme production of Pleurotus ostreatus growth in agroindustrial wastes. Braz. J. Microbiol. 2012, 43, 1508-1515. [CrossRef] [PubMed]

55. Poudyal, H.; Panchal, S.K.; Waanders, J.; Ward, L.; Brown, L. Lipid redistribution by $\alpha$-linolenic acid-rich chia seed inhibits stearoyl-CoA desaturase-1 and induces cardiac and hepatic protection in diet-induced obese rats. J. Nutr. Biochem. 2012, 23, 153-162. [CrossRef] [PubMed]

56. Da Silva, B.P.; Kolba, N.; Duarte Martino, H.S.; Hart, J.; Tako, E. Soluble extracts from chia seed (Salvia hispanica L.) affect brush border membrane functionality, morphology and intestinal bacterial populations in vivo (Gallus gallus). Nutrients 2019, 11, 2457. [CrossRef] [PubMed]

57. Bodoira, R.M.; Penci, M.C.; Ribotta, P.D.; Martínez, M.L. Chia (Salvia hispanica L.) oil stability: Study of the effect of natural antioxidants. Food Sci. Technol. 2017, 75, 107-113. [CrossRef]

58. Melo, D.; MacHado, T.B.; Oliveira, M.B.P.P. Chia seeds: An ancient grain trending in modern human diets. Food Funct. 2019, 10, 3068-3089. [CrossRef]

59. Ciftci, O.N.; Przybylski, R.; Rudzińska, M. Lipid components of flax, perilla, and chia seeds. Eur. J. Lipid Sci. Technol. 2012, 114, 794-800. [CrossRef]

60. Nitrayová, S.; Brestenský, M.; Heger, J.; Patráš, P.; Rafay, J.; Sirotkin, A. Amino acids and fatty acids profile of chia (Salvia hispanica L.) and flax (Linum usitatissimum L.) seed. Potravinarstvo 2014, 8, 267-275. [CrossRef]

61. Peiretti, P.G.; Gai, F. Fatty acid and nutritive quality of chia (Salvia hispanica L.) seeds and plant during growth. Anim. Feed Sci. Technol. 2009, 148, 267-275. [CrossRef] 
62. Silveira Coelho, M.; de las Mercedes Salas-Mellado, M. Chemical characterization of chia (Salvia hispanica L.) for use in food products. J. Food Nutr. Res. 2014, 2, 263-269. [CrossRef]

63. Álvarez-Chávez, L.M.; Valdivia-López, M.d.l.A.; Aburto-Juárez, M.d.L.; Tecante, A. Chemical characterization of the lipid fraction of mexican chia seed (Salvia hispanica L.). Int. J. Food Prop. 2008, 11, 687-697. [CrossRef]

64. Rossi, S.A.; Oliva, M.E.; Ferreira, M.R.; Chicco, A. Dietary chia seed induced changes in hepatic transcription factors and their target lipogenic and oxidative enzyme activities in dyslipidaemic insulin-resistant rats. Br. J. Nutr. 2013, 109, 1617-1627. [CrossRef] [PubMed]

65. Valdivia-López, M.Á.; Tecante, A. Chia (Salvia hispanica): A Review of Native Mexican Seed and its Nutritional and Functional Properties. Adv. Food Nutr. Res. 2015, 75, 53-75. [CrossRef]

66. Reyes-Caudillo, E.; Tecante, A.; Valdivia, M. Dietary fibre content and antioxidant activity of phenolic compounds present in Mexican chia (Salvia hispanica L.) seeds. Food Chem. 2008, 107, 656-663. [CrossRef]

67. Marineli, R.; Lenquiste, S.; Moraes, E.; Maróstica, M., Jr. Antioxidant potential of dietary chia seed and oil (Salvia hispanica L.) in diet-induced obese rats. Food Res. Int. 2015, 76, 666-674. [CrossRef]

68. Peláez, P.; Orona-Tamayo, D.; Montes-Hernández, S.; Valverde, M.E.; Paredes-López, O.; Cibrián-Jaramillo, A. Comparative transcriptome analysis of cultivated and wild seeds of Salvia hispanica (chia). Sci. Rep. 2019, 9, 9761. [CrossRef]

69. Bushway, A.A.; Belyea, P.R.; Bushway, R.J. Chia seed as a source of oil, polysaccharide, and protein. J. Food Sci. 1981, 46, 1349-1350. [CrossRef]

70. Sandoval-Oliveros, M.R.; Paredes-López, O. Isolation and characterization of proteins from chia seeds (Salvia hispanica L.). J. Agric. Food Chem. 2013, 61, 193-201. [CrossRef]

71. U.S. Department of Agriculture. Available online: https://fdc.nal.usda.gov/fdc-app.html\#/food-details/1100610/nutrients (accessed on 12 November 2021).

72. Martínez-Cruz, O.; Paredes-López, O. Phytochemical profile and nutraceutical potential of chia seeds (Salvia hispanica L.) by ultra high performance liquid chromatography. J. Chromatogr. A 2014, 1346, 43-48. [CrossRef]

73. Pellegrini, M.; Lucas-Gonzalez, R.; Sayas-Barberá, E.; Fernández-López, J.; Pérez-Álvarez, J.A.; Viuda-Martos, M. Bioaccessibility of phenolic compounds and antioxidant capacity of chia (Salvia hispanica L.) seeds. Plant Foods Hum. Nutr. 2018, 73, 47-53. [CrossRef]

74. Jin, F.; Nieman, D.C.; Sha, W.; Xie, G.; Qiu, Y.; Jia, W. Supplementation of milled chia seeds increases plasma ALA and EPA in postmenopausal women. Plant Foods Hum. Nutr. 2012, 67, 105-110. [CrossRef] [PubMed]

75. Amato, M.; Caruso, M.C.; Guzzo, F.; Galgano, F.; Commisso, M.; Bochicchio, R.; Labella, R.; Favati, F. Nutritional quality of seeds and leaf metabolites of chia (Salvia hispanica L.) from Southern Italy. Eur. Food Res. Technol. 2015, 241, 615-625. [CrossRef]

76. Da Silva, B.P.; Anunciação, P.C.; Matyelka, J.C.d.S.; Della Lucia, C.M.; Martino, H.S.D.; Pinheiro-Sant'Ana, H.M. Chemical composition of Brazilian chia seeds grown in different places. Food Chem. 2017, 221, 1709-1716. [CrossRef] [PubMed]

77. Marcinek, K.; Krejpcio, Z. Chia seeds (Salvia hispanica): Health promoting properties and therapeutic applications-A review. Roczniki Państwowego Zakładu Higieny 2017, 68, 123-129.

78. Capitani, M.I.; Spotorno, V.; Nolasco, S.M.; Tomás, M.C. Physicochemical and functional characterization of by-products from chia (Salvia hispanica L.) seeds of Argentina. Food Sci. Technol. 2012, 45, 94-102. [CrossRef]

79. Elshafie, H.S.; Aliberti, L.; Amato, M.; De Feo, V.; Camele, I. Chemical composition and antimicrobial activity of chia (Salvia hispanica L.) essential oil. Eur. Food Res. Technol. 2018, 244, 1675-1682. [CrossRef]

80. Marineli, R.d.S.; Moura, C.S.; Moraes, É.A.; Lenquiste, S.A.; Lollo, P.C.B.; Morato, P.N.; Amaya-Farfan, J.; Maróstica, M.R. Chia (Salvia hispanica L.) enhances HSP, PGC-1 $\alpha$ expressions and improves glucose tolerance in diet-induced obese rats. Nutrition 2015, 31, 740-748. [CrossRef]

81. Chicco, A.G.; D’Alessandro, M.E.; Hein, G.J.; Oliva, M.E.; Lombardo, Y.B. Dietary chia seed (Salvia hispanica L.) rich in a-linolenic acid improves adiposity and normalises hypertriacylglycerolaemia and insulin resistance in dyslipaemic rats. Br. J. Nutr. 2009, 101, 41-50. [CrossRef] [PubMed]

82. Fonte-Faria, T.; Citelli, M.; Atella, G.C.; Raposo, H.F.; Zago, L.; de Souza, T.; da Silva, S.V.; Barja-Fidalgo, C. Chia oil supplementation changes body composition and activates insulin signaling cascade in skeletal muscle tissue of obese animals. Nutrition $\mathbf{2 0 1 9}$ 58, 167-174. [CrossRef]

83. Da Silva, B.P.; Dias, D.M.; de Castro Moreira, M.E.; Toledo, R.C.L.; da Matta, S.L.P.; Della Lucia, C.M.; Martino, H.S.D.; PinheiroSant'Ana, H.M. Chia seed shows good protein quality, hypoglycemic effect and improves the lipid profile and liver and intestinal morphology of wistar rats. Plant Foods Hum. Nutr. 2016, 71, 225-230. [CrossRef]

84. Tavares Toscano, L.; Oliveira da Silva, C.S.; Monteiro de Almeida, A.E.; da Cruz Santos, A. Chia flour supplementation reduces blood pressure in hypertensive subjects. Plants Foods Hum. Nutr. 2014, 69, 392-398. [CrossRef] [PubMed]

85. Vuksan, V.; Whitham, D.; Sievenpiper, J.L.; Jenkins, A.L.; Rogovik, A.L.; Bazinet, R.P.; Vidgen, E.; Hanna, A. Supplementation of conventional therapy with the novel grain salba (Salvia hispanica L.) improves major and emerging cardiovascular risk factors in type 2 diabetes: Results of a randomized controlled trial. Diabetes Care 2007, 30, 2804-2810. [CrossRef]

86. Orona-Tamayo, D.; Valverde, M.; Nieto-Rendón, B.; Paredes-Lopez, O. Inhibitory activity of chia (Salvia hispanica L.) protein fractions against angiotensin I converting enzyme and antioxidant capacity. Food Sci. Technol. 2015, 64, 236-242. [CrossRef]

87. Segura-Campos, M.; Salazar-Vega, I.; Chel-Guerrero, L.; Betancur, D. Biological potential of chia (Salvia hispanica L.) protein hydrolysates and their incorporation into functional foods. LWT Food Sci. Technol. 2013, 50, 723-731. [CrossRef] 
88. Ho, H.; Lee, A.S.; Jovanovski, E.; Jenkins, A.L.; Desouza, R.; Vuksan, V. Effect of whole and ground Salba seeds (Salvia hispanica L.) on postprandial glycemia in healthy volunteers: A randomized controlled, dose-response trial. Eur. J. Clin. Nutr. 2013, 67, 786-788. [CrossRef] [PubMed]

89. Vuksan, V.; Jenkins, A.L.; Brissette, C.; Choleva, L.; Jovanovski, E.; Gibbs, A.L.; Bazinet, R.P.; Au-Yeung, F.; Zurbau, A.; Ho, H.V.T.; et al. Salba-chia (Salvia hispanica L.) in the treatment of overweight and obese patients with type 2 diabetes: A double-blind randomized controlled trial. Nutr. Metab. Cardiovasc. Dis. 2017, 27, 138-146. [CrossRef] [PubMed]

90. Medina-Urrutia, A.; Lopez-Uribe, A.R.; El Hafidi, M.; González-Salazar, M.d.C.; Posadas-Sánchez, R.; Jorge-Galarza, E.; del Valle-Mondragón, L.; Juárez-Rojas, J.G. Chia (Salvia hispanica)-supplemented diet ameliorates non-alcoholic fatty liver disease and its metabolic abnormalities in humans. Lipids Health Dis. 2020, 19, 96. [CrossRef]

91. Sargi, S.C.; Silva, B.C.; Santos, H.M.C.; Montanher, P.F.; Boeing, J.S.; Júnior, O.O.S.; Souza, N.E.; Visentainer, J.V. Antioxidant capacity and chemical composition in seeds rich in omega-3: Chia, flax, and perilla. Food Sci. 2013, 33, 541-548. [CrossRef]

92. Edwin, E.; Leo, M.; Segura-Campos, C.M. Neuroprotective effect from Salvia hispanica peptide fractions on pro-inflammatory modulation of HMC3 microglial cells. J. Food Biochem. 2020. [CrossRef]

93. Sharma, I.; Khan, W.; Parveen, R.; Alam, M.J.; Ahmad, I.; Ansari, M.H.R.; Ahmad, S. Antiurolithiasis activity of bioactivity guided fraction of bergenia ligulata against ethylene glycol induced renal calculi in rat. Biomed. Res. Int. 2017, 2017, 1-11. [CrossRef]

94. Makasana, A.; Ranpariya, V.; Desai, D.; Mendpara, J.; Parekh, V. Evaluation for the anti-urolithiatic activity of Launaea procumbens against ethylene glycol-induced renal calculi in rats. Toxicol. Rep. 2014, 1, 46-52. [CrossRef]

95. Bawari, S.; Negi Sah, A.; Tewari, D. Antiurolithiatic activity of Daucus carota: An in vitro study. Pharmacogn. J. 2018, 10, 880-884. [CrossRef]

96. Vertommen, J.; Van de Sompel, A.M.; Loenders, M.; Van der Velpen, C.; De Leeuw, I. Efficacy and safety of 1 month supplementation of SALBA (Salvia hispanica) grain to diet of normal adults on body parameters, blood pressure, serum lipids, minerals status and haematological parameters. Results of a pilot study. Nutr. Metab. Cardiovasc. Dis. 2017, 27, 138-146. [CrossRef]

97. Nieman, D.C.; Gillitt, N.; Jin, F.; Henson, D.A.; Kennerly, K.; Shanely, R.A.; Ore, B.; Su, M.; Schwartz, S. Chia seed supplementation and disease risk factors in overweight women: A metabolomics investigation. J. Altern. Complement. Med. 2012, 18, 700-708. [CrossRef]

98. Lindsay, J.O. Clinical, microbiological, and immunological effects of fructo-oligosaccharide in patients with Crohn's disease. Gut 2006, 55, 348-355. [CrossRef]

99. Kellow, N.J.; Coughlan, M.T.; Reid, C.M. Metabolic benefits of dietary prebiotics in human subjects: A systematic review of randomised controlled trials. Br. J. Nutr. 2014, 111, 1147-1161. [CrossRef]

100. Pacifici, S.; Song, J.; Zhang, C.; Wang, Q.; Glahn, R.; Kolba, N.; Tako, E. Intra amniotic administration of raffinose and stachyose affects the intestinal brush border functionality and alters gut microflora populations. Nutrients 2017, 9, 304. [CrossRef]

101. Yeung, C.K.; Glahn, R.E.; Welch, R.M.; Miller, D.D. Prebiotics and iron bioavailability-is there a connection? J. Food Sci. 2005, 70, 88-92. [CrossRef]

102. Miśta, D.; Króliczewska, B.; Pecka-Kiełb, E.; Kapuśniak, V.; Zawadzki, W.; Graczyk, S.; Kowalczyk, A.; Łukaszewicz, E.; Bednarczyk, M. Effect of in ovo injected prebiotics and synbiotics on the caecal fermentation and intestinal morphology of broiler chickens. Anim. Prod. Sci. 2017, 57, 1884. [CrossRef]

103. Sarao, L.K.; Arora, M. Probiotics, prebiotics, and microencapsulation: A review. Crit. Rev. Food Sci. Nutr. 2017, 57, 344-371. [CrossRef] [PubMed]

104. Pérez-Conesa, D.; López, G.; Ros, G. Effect of probiotic, prebiotic and synbiotic follow-up infant formulas on iron bioavailability in rats. Food Sci. Technol. Int. 2007, 13, 69-77. [CrossRef]

105. Weinborn, V.; Valenzuela, C.; Olivares, M.; Arredondo, M.; Weill, R.; Pizarro, F. Prebiotics increase heme iron bioavailability and do not affect non-heme iron bioavailability in humans. Food Funct. 2017, 8, 1994-1999. [CrossRef]

106. Przybylska-Balcerek, A.; Stuper-Szablewska, K. Phenolic acids used in the cosmetics industry as natural antioxidants. Eur. J. Med. Technol. 2019, 4, 24-32.

107. Vegan Cosmetics-Definition. Available online: https://biotechnologia.pl/kosmetologia/weganizm-nie-tylko-w-diecie-czyli-cowiemy-o-kosmetykach-weganskich, 16677\#: :text=Kosmetykiwega \%C5\%84skiebywaj\%C4\%85cz\%C4\%99stookre \%C5\%9Blane, eksperymentaminazwierz $\%$ C4\%99tach $\% 20 \% 5 \mathrm{~B} 1 \% 5 \mathrm{D}$ (accessed on 11 October 2021).

108. Natural Cosmetics-Definition. Available online: http://biotechnologia.pl/kosmetologia/artykuly/kosmetyki-naturalne,10830 (accessed on 11 October 2021).

109. Jeong, S.K.; Park, H.J.; Park, B.D.; Kim, I.-H. Effectiveness of topical chia seed oil on pruritus of end-stage renal disease (ESRD) patients and healthy volunteers. Ann. Dermatol. 2010, 22, 143. [CrossRef]

110. Opinion on the safety of 'Chia seeds (Salvia hispanica L.) and ground whole chia seeds' as a food ingredient. EFSA J. 2009, 7, 996. [CrossRef]

111. Borneo, R.; Aguirre, A.; Leon, A.E. Chia (Salvia hispanica L.) gel can be used as egg or oil replacer in cake formulations. J. Am. Diet. Assoc. 2010, 110, 946-949. [CrossRef]

112. Dos Reis Gallo, L.R.; Botelho, R.B.A.; Ginani, V.C.; de Lacerda de Oliveira, L.; Riquette, R.F.R.; dos Santos Leandro, E. Chia (Salvia hispanica L.) gel as egg replacer in chocolate cakes: Applicability and microbial and sensory qualities after storage. J. Culin. Sci. Technol. 2020, 18, 29-39. [CrossRef] 
113. Felisberto, M.H.F.; Wahanik, A.L.; Gomes-Ruffi, C.R.; Clerici, M.T.P.S.; Chang, Y.K.; Steel, C.J. Use of chia (Salvia hispanica L.) mucilage gel to reduce fat in pound cakes. LWT Food Sci. Technol. 2015, 63, 1049-1055. [CrossRef]

114. Zi, C.T.; Yang, L.; Xu, F.Q.; Dong, F.W.; Yang, D.; Li, Y.; Ding, Z.T.; Zhou, J.; Jiang, Z.H.; Hu, J.M. Synthesis and anticancer activity of dimeric podophyllotoxin derivatives. Drug Des. Dev. Ther. 2018, 12, 3393-3406. [CrossRef] [PubMed]

115. Ding, Y.; Lin, H.-W.; Lin, Y.-L.; Yang, D.-J.; Yu, Y.-S.; Chen, J.-W.; Wang, S.-Y.; Chen, Y.-C. Nutritional composition in the chia seed and its processing properties on restructured ham-like products. J. Food Drug Anal. 2018, 26, 124-134. [CrossRef] [PubMed]

116. Sebastiani, G.; Herranz Barbero, A.; Borrás-Novell, C.; Alsina Casanova, M.; Aldecoa-Bilbao, V.; Andreu-Fernández, V.; Pascual Tutusaus, M.; Ferrero Martínez, S.; Gómez Roig, M.; García-Algar, O. The effects of vegetarian and vegan diet during pregnancy on the health of mothers and offspring. Nutrients 2019, 11, 557. [CrossRef] [PubMed]

117. Fernández-López, J.; Viuda-Martos, M.; Sayas-Barberá, M.E.; Navarro-Rodríguez de Vera, C.; Lucas-González, R.; Roldán-Verdú, A.; Botella-Martínez, C.; Pérez-Alvarez, J.A. Chia, quinoa, and their coproducts as potential antioxidants for the meat industry. Plants 2020, 9, 1359. [CrossRef]

118. Carvalho, C.; Católica, U.; Bosco, D.; Regina, C.; Arfux, B.; Menegati, C.D.F.; Moreira, R. Cultivo in vitro de Salvia hispanica. Rev. Eletrônica Gestão 2015, 19, 1555-1560.

119. Zayova, E.; Nikolova, M.; Dimitrova, L.; Petrova, M. Comparative study of in vitro, ex vitro and in vivo propagated Salvia hispanica (chia) plants: Morphometric analysis and antioxidant activity. AgroLife Sci. J. 2016, 5, 166-174.

120. Yadav, A.; Kothari, S.L.; Kachhwaha, S.; Joshi, A. In vitro propagation of chia (Salvia hispanica L.) and assessment of genetic fidelity using random amplified polymorphic DNA and intersimple sequence repeat molecular markers. J. Appl. Biol. Biotechnol. 2019, 7, 42-47. [CrossRef]

121. Marconi, P.L.; López, M.C.; De Meester, J.; Bovjin, C.; Alvarez, M.A. In vitro establishment of Salvia hispanica L. plants and callus. Biotecnol. Veg. 2013, 4, 203-207.

122. Bueno, M.; Di Sapio, O.; Barolo, M.; Villalonga, M.E. In vitro response of different Salvia hispanica L. (Lamiaceae) explants. Mol. Med. Chem. 2010, 21, 125-126. 